Yemets O. I.

Candidate of Economic Sciences, Associate Professor at the Department of Theoretical and Applied Economics Vasyl Stefanyk Precarpathian National University

Shelenko D. I.

Doctor of Economic Sciences, Associate Professor at the Department of Theoretical and Applied Economics Vasyl Stefanyk Precarpathian National University

Balaniuk I. F. Doctor of Economic Sciences, Professor, Head of the Department of Accouting and Audit Vasyl Stefanyk Precarpathian National University

\title{
INVESTMENT ENVIRONMENT FOR THE DEVELOPMENT OF AMALGAMATED TERRITORIAL COMMUNITIES
}

\section{Summary}

The economic development of the Ukrainian society requires the active participation of all institutions: state authorities, communities and local selfgovernment bodies to achieve the strategic goal of improving the quality of life of the population to the European standards. The article analyzes the structure of the nominal gross domestic product (GDP) of Ukraine in the national currency, determines the absolute growth and growth rates of GDP for 2014-2018, the relationship between gross accumulation and capital investments in order to determine the priority directions of investment activity in conditions of decentralization. By choosing the country's most appropriate model of decentralization, it is already possible in the medium term to expect qualitative positive results.

Priority directions of the activity of the amalgamated territorial communities (ATC) of Ukraine are, first of all, repairment of highways, assistance in the preparation of urban planning documentation and the development of alternative energy. This article is necessary in order to create a favorable environment for the full development of a person, the provision of quality public services in a specific territorial community. Particular attention is paid to discussing the share of GDP components, dynamics of gross accumulation and capital investment over 5 years.

In solving the tasks, we have used a number of methods of research: methods of statistical analysis for assessing the dynamics of GDP, share of consumer spending, gross accumulation, exports and imports; methods of analysis for determining the structure of GDP, method of comparison for studying the views of different authors on strategic decentralization reforms in ATC. 


\section{Introduction}

Local self-government as a factor in the democratization of social life and decentralization of governance is a prerequisite for the establishment of a civil society, the approach of power to the people. Changes in the system of local self-government in Ukraine are caused by contradictions and problems in its regulatory, organizational, financial and information provision, and the constitutionally defined subject of local self-government - the territorial community - has not acquired its true status for a long time. All this testifies to the lack of certainty of the current state policy of development of the local self-government, which should include the interests of the state, the amalgamated territorial community and the individual.

The Ukrainian vector of the European integration course and the future democratization of society, the decentralization of power on the principles of subsidiarity remain the priorities.

Studying the experience of economic development of the amalgamated territorial communities and its use is devoted to the work of scientists, in particular, the processes of decentralization, reforms and their results in foreign countries for the successful implementation of the latter in Ukraine [13, p. 120]; the impact of agricultural enterprises on the development of amalgamated territorial communities [21, p. 42]; regulation of the development of territorial communities [22, p. 52]; disadvantages of a decentralized system [27, p. 84]; decentralization in Poland was carried out in two phases, the first phase in 1990 and the second phase in 1999 [16, p. 8].

Significant shortcomings of the decentralized system, in particular, the absence of guarantees that the price information obtained in one part of the system will become a general property [27, p. 84].

Instrumental alternate method for evaluating government decision-making programs and social welfare functions [19, p. 520].

This paper explores the relationship between natural resource revenues and expenditure decentralization. We find that expenditure decentralization is highly persistent $[2$, p. 55].

Bondaruk T.G. and Bondaruk I.S. [5, p. 16] emphasize the theoretical and methodological principles of state regulation of financial support of municipal authorities in the conditions of decentralization, indicating that the difference in the interests of social groups arises in the uneven development of the territory, as well as in social inequality.

Local economic growth is being seen as a stable, forward-looking development, as a regional economic recovery based on intensive development, an increase in the volume of gross regional product per capita [30, p. 45], privatization of state-owned enterprises as one of the elements ofdecentralization [16, p. 780], reforms in rural systems [14, p. 95-97].

The purpose of the article is to analyze the structure of the nominal GDP of Ukraine in the national currency, to determine the absolute growth and GDP growth rates for 2014-2018, in order to determine the priority directions of investment activity in the conditions of decentralization, identify the positive impact of decentralization on the development of ATC. 


\section{Part 1. Investment activity in the conditions of decentralization of territorial communities}

Economic development of the Ukrainian society requires an active participation of all institutions: state power, communities and local selfgovernment bodies to achieve the strategic goal of raising the quality of life of the population to the European standards. Practice has proved that the prerequisite for sustainable national economic development is the selfsufficiency of territorial communities, their ability to rationally use their available resources. Proceeding from the above, the development of new mechanisms of management of local economic development, which would allow combining the efforts and interests of all subsects of development: executive authorities, local self-government, local business and, of course, the community itself, is becoming extremely important.

In a context of overcoming the consequences of the crisis, regardless of the level of development of national economies, governments of many countries, use fiscal instruments of influence on economic growth to intensify investment activity. One of the factors stimulating macroeconomic dynamics is the improvement of the state budget policy of Ukraine in the sphere of expenditures as an important priority of the implementation of the social and economic policy of the state.

As the experience of developed countries convinces, there is an interaction between economic development of the country and fiscal policy in the sphere of state expenditures: on the one hand, the rates of economic growth and corresponding changes in the GDP of the country make adjustments to the formation of the volume and structure of public expenditures, and, on the other hand, state financing affects on the social and economic development of the country and the dynamics of macroeconomic indicators. The positions of scientists regarding the impact of public expenditures on economic growth differ. In our opinion, this is due to the fact that scholars are studying the relationship between the pace of economic growth and the dynamics of different components of GDP. Let us consider the structure of Ukraine's GDP for 2014-2018, which is presented in Table 1.

Analysis of the share of GDP components over 5 years allows us to conclude that consumer spending have tendency to decrease, gross accumulation is gradually increasing, but the net export balance always has a negative value.

There is a close correlation between gross capital formation and capital investment, which ultimately has a positive effect on the GDP growth trend in Ukraine, Figure 1.

The generally accepted starting point is that public spending contributes to the goal of economic growth. The economic justification of state interference in the economy in the conditions of inefficient functioning of the market mechanism and for the distribution of resources obtained as a result of compensatory measures is based, in particular, on this thesis. However, an American economist R. Barro [3, p. 410], during studying the interplay of the 
dynamics of the share of government consumption in GDP and the pace of economic growth, concluded their negative relationship.

Table 1

Structure of Ukraine's GDP by end-use from 2014 to 2018 (million UAH)

\begin{tabular}{|c|c|c|c|c|c|c|c|c|c|}
\hline $\begin{array}{c}\text { Nominal GDP } \\
\text { per year }\end{array}$ & \multicolumn{2}{c|}{$\begin{array}{c}\text { Consumer } \\
\text { Costs }\end{array}$} & \multicolumn{2}{c|}{$\begin{array}{c}\text { Gross } \\
\text { accumulation }\end{array}$} & \multicolumn{2}{c|}{$\begin{array}{c}\text { Export of } \\
\text { goods and } \\
\text { services }\end{array}$} & \multicolumn{2}{c|}{$\begin{array}{c}\text { Import of } \\
\text { goods and } \\
\text { services }\end{array}$} \\
\hline year & Once & Amount & $\begin{array}{c}\text { \% } \\
\text { GDP }\end{array}$ & Amount & $\begin{array}{c}\text { \% } \\
\text { GDP }\end{array}$ & Amount & $\begin{array}{c}\text { \% } \\
\text { GDP }\end{array}$ & Amount & $\begin{array}{c}\text { \% } \\
\text { GDP }\end{array}$ \\
\hline 2014 & 1566728 & 1409772 & 90.0 & 220968 & 14.1 & 770121 & 49.2 & -834133 & -53.2 \\
\hline 2015 & 1979458 & 1715636 & 86.7 & 303297 & 15.3 & 1044541 & 52.8 & - & -54.8 \\
\hline 2016 & 2383182 & 2018854 & 84.7 & 512830 & 21.5 & 1174625 & 49.3 & $\begin{array}{c}- \\
1323127\end{array}$ & -55.5 \\
\hline 2017 & 2982920 & 2552525 & 85.6 & 618914 & 20.7 & 1430230 & 47.9 & - & -54.3 \\
\hline 2018 & 3558706 & 3196756 & 89.8 & 667953 & 18.8 & 1608890 & 45.2 & $\begin{array}{c}- \\
1618749\end{array}$ & -53.8 \\
\hline
\end{tabular}

Source: [18]

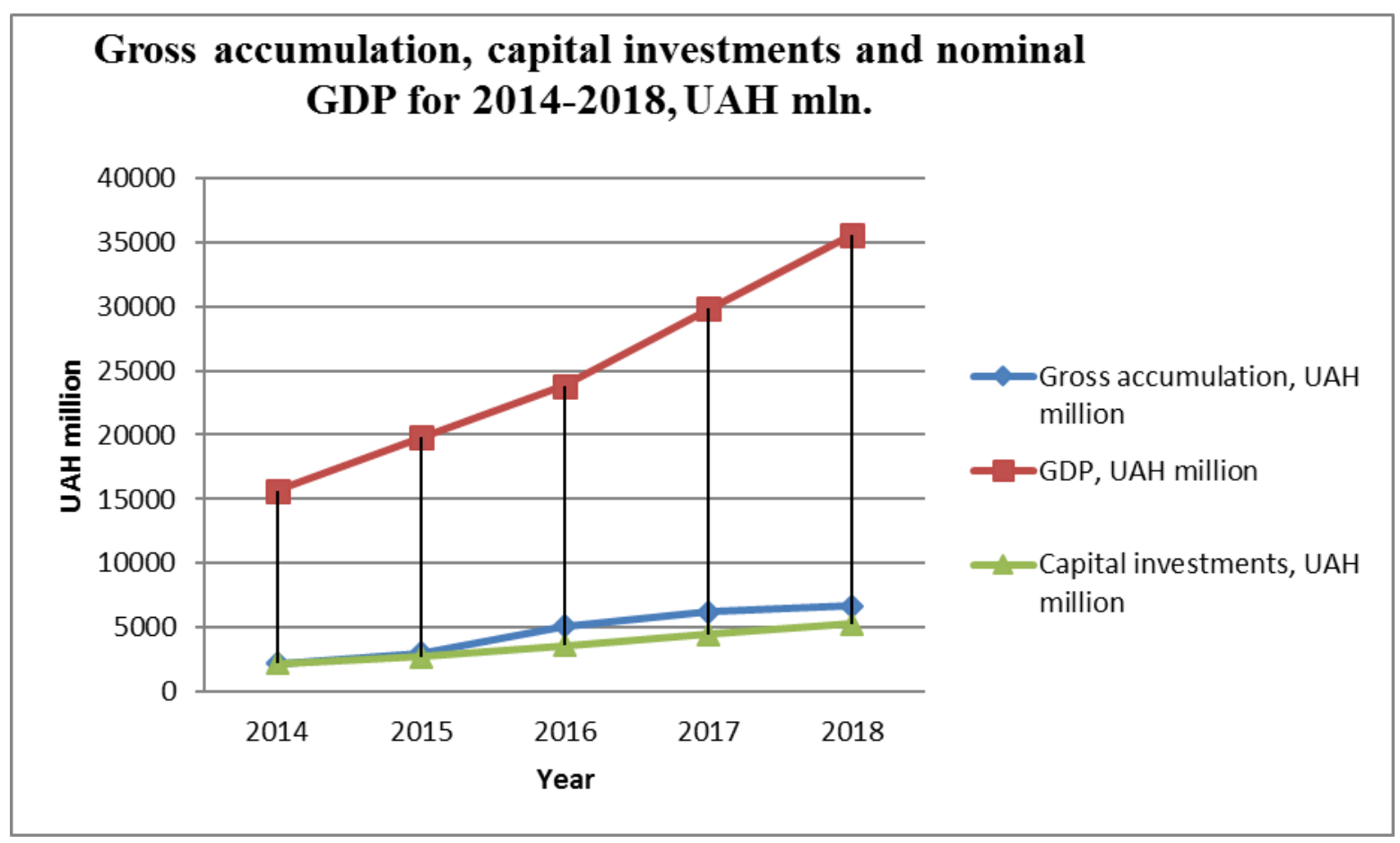

Figure 1. Gross accumulation, capital investments and nominal GDP of Ukraine for 2014-2018, mln

The unstable but positive trend in the nominal GDP growth rate for Ukraine for 2014-2018 in the national currency has been presented in Table 2.

The experience of industrialized countries testifies to the existence of a disproportionate correlation between aggregate government expenditures and 
economic growth. In particular, the excessive concentration of expenditures on the state level is hampering the development of the economy, therefore, economically developed countries and developing countries began to reduce the share of government expenditures. Also, the negative impact of aggregate state consumption on economic growth with the positive effect of educational expenditures was highlighted in the writings of Larry Diamond [9].

Table 2

Nominal GDP of Ukraine for 2014-2018

\begin{tabular}{|c|c|c|c|}
\hline Year & $\begin{array}{c}\text { Nominal GDP per } \\
\text { year }\end{array}$ & $\begin{array}{c}\text { Absolute increase, } \\
\text { mln. }\end{array}$ & $\begin{array}{c}\text { Rate of growth, } \\
\text { \% }\end{array}$ \\
\hline 2014 & 1566728 & 111797 & $7.7 \%$ \\
\hline 2015 & 1979458 & 412730 & $26.3 \%$ \\
\hline 2016 & 2383182 & 403724 & $20.4 \%$ \\
\hline 2017 & 2982920 & 599738 & $25.2 \%$ \\
\hline 2018 & 3558706 & 575786 & $19.3 \%$ \\
\hline
\end{tabular}

Source: [25]

According to A.V. Stavytskyi [24], the existing structure of public expenditures in Ukraine is not able to affect the economy of the state positively [20]. This explains the fact that domestic realities contradict the economic theory: the increase of state expenditures should have a positive impact on macroeconomic indicators, which is not observed in our country. The scientist also recommends revising the structure and size of expenditures for economic activity and capital expenditures in accordance with the situation in Ukraine: occupation of parts of land, anti-terrorist operation, signing of an agreement with the European Union. Such actions will provide an opportunity to increase the efficiency of public expenditures, and, therefore, ensure the maximum rate of economic growth at the expense of lower budget expenditures. All this determines the necessity of changes in the structure of public expenditures, the delegation of part of the powers to the local level. With the help of the state budget, funds are mobilized not only for financing social events, but also for redistribution of a certain part of GDP in order to ensure social justice [4].

\section{Part 2. The impact of decentralization on the investment development}

In the conditions of overcoming military aggression, further rebuilding of the country and its economic reorientation, it is important to carry out a balanced budget policy and to increase control over the efficiency of spending budget funds. That is, it is necessary to start a new system of state expenditures in the country, which would involve strengthening the role of local budgets. Changing the conditions for the formation and implementation of local budgets as a significant component of the budget system can positively affect its balance and financial security of the country as a whole. 
The conducted study [1, p. 1069] contains an analysis of the negative impact of corruption on the economic security of states. In particular, it has been determined that this impact is manifested in the growth of the shadow economy, deformation of competition mechanisms according to the principles of a market economy, emergence of inefficient private holders, reduced efficiency of distribution and use of budget funds, deterioration of investment climate, etc.

The fiscal decentralization initiative should encourage local communities to fill their estimates more efficiently, switch to self-sufficiency and costeffectively plan. Accordingly, sources of filling local budgets have been expanded by transferring from the state budget to a number of tax places, as well as the introduction of new fees.

Foreign direct investment (FDI) is a long-term investment of material assets by non-resident companies into the economy (for example, for the purpose of organizing and building enterprises).

Direct foreign investment is the most desirable form of investment for emerging economies because it allows for large projects to be implemented; besides, new technologies, new practices of corporate governance, etc. come to the country.

So far as decentralization in Ukraine has been introduced since 2014, it is advisable to consider the dynamics of foreign direct investment from this period in Table 3.

Table 3

Foreign Direct Investment in Ukraine for 2014-018 (million USD)

\begin{tabular}{|c|c|c|c|c|c|c|}
\hline \multirow{2}{*}{ Year } & \multicolumn{2}{|c|}{$\begin{array}{c}\text { Direct foreign } \\
\text { investment in } \\
\text { Ukraine }\end{array}$} & \multicolumn{2}{c|}{$\begin{array}{c}\text { Direct foreign } \\
\text { investment from } \\
\text { Ukraine }\end{array}$} & \multicolumn{2}{c|}{ Balance } \\
\cline { 2 - 7 } & Amount & $\begin{array}{c}\text { Absolute } \\
\text { increment }\end{array}$ & Amount & $\begin{array}{c}\text { Absolute } \\
\text { increment }\end{array}$ & $\begin{array}{c}\text { Absolute } \\
\text { increment }\end{array}$ & $\begin{array}{c}\text { Rate of } \\
\text { growth, } \\
\text { \% }\end{array}$ \\
\hline 2014 & 410 & - & 111 & - & +299 & - \\
\hline 2015 & 2961 & 2551 & -51 & -162 & +3012 & $907.4 \%$ \\
\hline 2016 & 3284 & 323 & 16 & 67 & +3268 & $8,5 \%$ \\
\hline 2017 & 2202 & -1082 & 8 & -8 & +2194 & $-32,9 \%$ \\
\hline 2018 & 2355 & 153 & -5 & -13 & +2360 & $7,6 \%$ \\
\hline
\end{tabular}

Source: [18]

from 2014 - without taking into account the occupied territories (Crimea, Sevastopol, parts of Donbass)

The analysis of the digital information of the table shows that foreign direct investment in Ukraine is far ahead of foreign direct investment from Ukraine. Investment balance of 299 million USD in 2014 has increased by almost 10 times in 2018 , which is confirmed by the positive impact of decentralization in Ukraine. 
Despite the increase in capital investment in the domestic economy in 2018, their level per capita (450 USD) is almost four times smaller than in neighboring Poland (1,766 USD).

The current social and political situation in Ukraine has activated a sharp political debate on the improvement of its state and territorial system in order to expand autonomy of the regions.

The talk of decentralization dates back to the beginning of 2014, when a direct request for this was accomplished by the Revolution of Wisdom. It should be noted that this was the first time that the Ukrainian history on the constitutional level was about the distribution of powers not «horizontally» («President - Parliament - Government»), but «vertically» (between centers and regions).

World experience teaches that decentralization can play a positive role for favorable conditions for the development of settlements, regions and the country as a whole. It is the amalgamated territorial communities that have the capacity to provide quality services to the population and economic entities together with the state institutions, creating a certain balance that ensures the economic potential of a particular territory.

The institutional architecture of the state and its administrative and territorial units must be flexible and consistently adapted to the conditions of the country's development.

In the process of budget decentralization of Ukraine it is necessary to use effective directions of its realization and to follow European experience, in particular: to eliminate contradictory and ambiguous issues in certain provisions of the current legislation in the sphere of local self-government; to conduct a scientifically grounded administrative and territorial unit for the consolidation of territorial communities taking into account the levels of their fiscal ability [6, p. 125]; to ensure a clear distribution of expenditures with the simultaneous distribution of spheres of responsibility for their implementation; to expand the sphere of authority of local self-government bodies; to increase the volume of own revenues of local government budgets (in particular, by including the ecological tax in full to the budget of the corresponding level, optimizing the mechanisms of taxation of real estate and labor resources with low-elastic demand, enrollment of the personal income tax on the place of residence, etc.); to improve the system of inter-budgetary relations organization. Territorial communities should become active participants in the provision of social and economic development of territories, and local self-government bodies should be interested in increasing the volume of their own revenues of the basic level budgets. The volume and quality of the services provided must correspond to the size of the taxes paid by the members of the amalgamated territorial communities. Then, one can assert the possibility of a focused and active work of local self-government bodies in ensuring social and economic development and full use of the fiscal and tax potential of administrative and territorial units. However, considerable attention should be given to the economic development of communities. 
At the current stage, fiscal policy of Ukraine has a social orientation, because the share of expenditures on the social sphere, education, health care prevails over development expenditures. However, the priority funding of social development is not an indicator of economic development, but is a peculiar budget for food. The increase in production volumes, tax revenues, infrastructure development, and the growth of the gross regional product is possible due to an increase in the volume of expenditures of a capital nature. For Ukraine, it is important to increase the volume of capital expenditures of local budgets as a lever of regulation and stimulation of the development of the region's economy in the territorial and sectoral aspect and from the position of forming the proper level of living and welfare of the population.

Budget decentralization in Ukraine is necessary in order to create favorable conditions for universal development of a person, provision of quality public services in a specific city, township, and village. In the process of budget decentralization, it is important to ensure a clear separation of powers, responsibilities of different levels of government and an increase in the volume of own revenues of the budgets of the territorial communities. The main strategic task of the implementation of budget decentralization is to ensure the economic development of administrative and territorial units.

Thus, it should be noted that decentralization is the key to effective territorial development, the road to democratization, real democracy. The obvious need for reforming both the system of local self-government and the entire territorial organization of power in Ukraine led to the appearance of a sufficiently large number of relevant projects. At the stage of direct implementation of the Concept of the Reform of local self-government and territorial organization of the authorities in Ukraine, we have a newly created legislative framework for the implementation of the rights of territorial communities on the sites, which corresponds to the vector of the European development of local self-government.

The relevant financial support of the territorial communities in providing them with authority in the controlled territories remains the most urgent issue. Further development requires the promotion of self-government units to implement their powers, as well as educational work on communicating the opportunities provided by the legal framework to all members of the community effectively. Thus, the process of reforming local self-government is complex and requires a further multidimensional approach to the development and implementation of changes in the current legislation of Ukraine in this area.

The existence of any democratic, legal state and civil society, as well as processes of European integration, foresees the creation of an effective decentralized system of public power, based on the rule of law, democracy, recognition of a person with the highest social value. These tasks cannot be implemented without a full system of local self-government. The tasks for constitutional science are to seek and ensure such mechanisms that would maintain optimal relations between different levels of government, provide territorial integrity and develop democracy. This approach eliminates the split 
of power, which leads to political instability and weakening of the state and its institutions, and ultimately excludes collisions between society and the state [7, p. 106].

In the current political unstable situation in Ukraine, the economic and social crisis, external aggression of decentralization, according to O. Skrypniuk [23], can lead to deepening existing and the emergence of new negative tendencies in the development of the state and society. This should be anticipated and prepared for such challenges:

- deepening of regional identities among the population, separatist sentiment in some regions;

- increased arbitrariness of officials and local elites and increased dissatisfaction of the population of the regions with the authorities, including the central one, which would demonstrate the inability to protect the interests and rights of regional communities;

- the danger of centric tendencies due to the extremely low level of the responsibility of the state to the administrative and territorial entities [6, p. 24].

According to one of the ideologues of decentralization [26], the reform, which is being conducted in Ukraine, is uniquely Ukrainian and does not copy the experience of any other country. It has three components:

- the reform of the territorial organization of power;

- local self-government reform;

- reform of regional policy.

An essential component of decentralization is the number of ATC residents. There should be a lot of interest in the number of communities included in the new ATC. The law on voluntary adherence of communities allows ATC to join new communities, increasing the territory and the population, and hence the ability to provide quality services.

The Ministry of Regional Development, Construction and Housing and Communal Services of Ukraine introduced a financial monitoring of ATC capabilities based on the following indicators:

1. The volumes of own resources in the community budget per one inhabitant. This indicator allows you to see the prospects of revenues due to land registry, real estate, excise tax. This indicates the effectiveness of management decisions on sites.

2. The dependence of the community on the state budget, the level of its economic self-sufficiency.

3. Community expenditures for management personnel. The effectiveness of power is determined by the quality of life in the community. If revenue for managerial staff increases, then infrastructure costs should increase.

The level of effectiveness of ATC will be assessed on the basis of financial indicators, which will enable to determine the need for attracting investment and labor resources, management decisions on health care, planning of territories, development of administrative services. In addition, monitoring will allow ATC to really assess social and economic prospects for the development of their community. 
The reform of decentralization in Ukraine needs to be implemented at a faster pace, illustrating promising achievements, this will enable effective managers to find places to take advantage of new opportunities successfully. They receive additional funding, commit themselves and responsibilities, and work well in the interests of communities. This increases the confidence of people in the activities of the mayors, whose rating will increase.

For the main positive results of financial decentralization, it is expedient to include the annual growth of the volume of own resources of local budgets, their share in the structure of the consolidated budget of Ukraine, the possibility of local self-government bodies to direct funds to development expenditures, the implementation of infrastructure projects, etc.

Despite the lack of experience in the realization of investment projects, the communities proved their ability to work for a «result» - they mastered $95 \%$ of the 1 billion USD subvention for the development of infrastructure [11].

\section{Part 3. Decentralization reform of Ivano-Frankivsk region}

Dynamics of development of capital investments during 2014-2018. Enterprises and organizations of the region at the expense of all sources of financing is presented in Table 4.

Table 4

Capital investment by type of assets in Ivano-Frankivsk region for 2014-2018, ths. UAH.

\begin{tabular}{|l|c|c|c|c|c|}
\hline \multirow{2}{*}{\multicolumn{1}{|c|}{ Indexes }} & \multicolumn{5}{|c|}{ Years } \\
\cline { 2 - 6 } & $\mathbf{2 0 1 4}$ & $\mathbf{2 0 1 5}$ & $\mathbf{2 0 1 6}$ & $\mathbf{2 0 1 7}$ & $\mathbf{2 0 1 8}$ \\
\hline $\begin{array}{l}\text { Capital investment, } \\
\text { including: }\end{array}$ & 6837474 & 9609271 & 7947642 & 9707832 & 9393710 \\
\hline $\begin{array}{l}\text { investment in tangible } \\
\text { assets }\end{array}$ & 6821507 & 9581106 & 7900924 & 9647077 & 9221431 \\
\hline $\begin{array}{l}\text { investment in intangible } \\
\text { assets }\end{array}$ & 15967 & 28165 & 46718 & 60755 & 172279 \\
\hline
\end{tabular}

Source: [17].

The main sources of financing of capital investments remain the own funds of enterprises and organizations, which account for about half of the total volume (Table 5).

The largest share of capital investment was directed to the development of industrial enterprises, construction, agriculture, forestry, and fisheries (Table 6).

Such factors as population size, number of children, area, availability of economic potential, volume of financial resources, network of social and cultural sphere influence the ability of ATC to provide quality public services.

Another positive factor of financial decentralization is the transfer to the local budget of the excise tax, as well as the tax on real estate, due to which many communities have become «golden». 
With such a specialty of financial decentralization, which lead to the filling of local budgets, we can conclude that expediency of investing in the economy of ATC.

Along with the positive aspects, we see the disadvantage that we had to observe in part of the expenditures of local budgets: it is a fool of the spending agents on the ground (heads of ATC), the essence of the concept of «strategy».

Table 5

Capital investment by sources of financing in Ivano-Frankivsk region for 2014-2018, ths. UAH.

\begin{tabular}{|l|c|c|c|c|c|}
\hline \multirow{2}{*}{ Indexes } & \multicolumn{5}{c|}{ Years } \\
\cline { 2 - 6 } & $\mathbf{2 0 1 4}$ & $\mathbf{2 0 1 5}$ & $\mathbf{2 0 1 6}$ & $\mathbf{2 0 1 7}$ & $\mathbf{2 0 1 8}$ \\
\hline $\begin{array}{l}\text { Total, } \\
\text { incl. at the expense of }\end{array}$ & 6837474 & 9609271 & 7947642 & 9707832 & 9393710 \\
\hline the state budget funds & 55106 & 127904 & 199498 & 334945 & 378834 \\
\hline funds of local budgets & 236825 & 577842 & 916284 & 1250310 & 1524812 \\
\hline $\begin{array}{l}\text { own funds of enterprises and } \\
\text { organizations }\end{array}$ & 2857195 & 6020902 & 4633362 & 4633290 & 5203931 \\
\hline bank loans and other loans & 636579 & 276214 & 163499 & 1108996 & 362566 \\
\hline funds of foreign investors & 362530 & 13399 & $\mathrm{c}$ & $\mathrm{c}$ & $\mathrm{c}$ \\
\hline $\begin{array}{l}\text { funds of the population for } \\
\text { housing construction }\end{array}$ & 2171169 & 2112216 & 1820034 & 1940293 & 1682781 \\
\hline other sources of funding & 518070 & 480794 & $\mathrm{c}$ & $\mathrm{c}$ & $\mathrm{c}$ \\
\hline
\end{tabular}

Symbol (c) - data are not made public in order to ensure compliance with the requirements of the Law of Ukraine «On State Statistics» regarding the confidentiality of statistical information.

Source: [17]

Table 6

Capital investment for certain types of economic activity in Ivano-Frankivsk region for 2014-2018, ths. UAH.

\begin{tabular}{|l|c|c|c|c|c|}
\hline \multirow{2}{*}{\multicolumn{1}{|c|}{ Indexes }} & \multicolumn{5}{|c|}{ Years } \\
\cline { 2 - 6 } & $\mathbf{2 0 1 4}$ & $\mathbf{2 0 1 5}$ & $\mathbf{2 0 1 6}$ & $\mathbf{2 0 1 7}$ & $\mathbf{2 0 1 8}$ \\
\hline Total & 6837474 & 9609271 & 7947642 & 9707832 & 9393710 \\
\hline $\begin{array}{l}\text { Agriculture, forestry } \\
\text { and fisheries }\end{array}$ & 409995 & 989485 & 534766 & 859896 & 1151242 \\
\hline Industry & 2591175 & 2046016 & 2751432 & 3624219 & 3031181 \\
\hline Construction & 2725532 & 2772570 & 2172135 & 2564335 & 281966 \\
\hline
\end{tabular}

Source: [17]

Based on the above information, we can propose a list of strategic directions:

1. Today, ATC is thinking about how to make money and invest in what is needed today to make a profit tomorrow. 
2. Attempts to create communities that are capable of paying taxes and retaining oneself, seeking new tax bases and promoting the shadow economy $[29$, p. 376].

3. To develop perspective plans for the association of territorial communities in order to avoid creating insolvent communities.

Ensuring social and economic growth at the level of territorial communities - villages, townships and cities is becoming increasingly relevant in today's market conditions in Ukraine.

Thanks to the decentralization reform in Ivano-Frankivsk region, 31 ATCs have been already operating, which are currently working to ensure their own ability and qualitative fulfillment of all those powers transferred to ATC at the time of unification [8].

In the process of formation and development of ATC, everyone worked to increase financial resources. As a result, due to decentralization, the budgets of territorial communities of Ivano-Frankivsk region increased by 2.5-4 times. During 2018, the budgets of the region community received 334 million UAH of own income. For 2019, 453 million UAH is envisaged [8].

State support is an important constituent element in the period of community formation. During 2016-2019, the amalgamated territorial communities of Ivano-Frankivsk region received about 3 billion UAH of transfers from the state budget, in particular: educational subventions 1.35 billion UAH; medical subvention - 433 million UAH; basic grant 464 million UAH; additional grant for education and health care 235 million UAH; infrastructure subvention - 130 million UAH.

It is important that more than 130 million UAH of infrastructure subventions will be fully developed for three consecutive years, which is 275 projects implemented on improved social infrastructure, purchased equipment, renovated utility roads, etc. From 2014 to 2018, state support for the development of territorial communities and the development of their infrastructure has increased by 39 times.

Decentralization and joint activities of the heads of the ATC stimulated new receipts in their budgets. In particular, such are the land tax on forestry land and rent for main utilities, the proceeds of which in the first quarter of 2019 amounted to 1.3 million UAH (forecast by the end of the year was 7 million UAH).

In 2018, 20 territorial communities of Ivano-Frankivsk region received the communal property of agricultural land outside settlements with a total area of 13,000 ha [10].

In addition, thanks to the coordinated work of the heads of the ATC, representatives of the business, the public sector and with the support of the Ivano-Frankivsk Center for Local Self-Government Development (U-LEAD Program with Europe), the Association of Ukrainian Cities, DOBRE-15 programs, the Prykarpattia have developed the Strategies for Social and Economic Development - this is a document that defines the directions for the joint creation of future communities. 
It should be emphasized that public services have become closer to the inhabitants of communities. The quality and accessibility of service delivery are important for ATCs, therefore, communities contribute to the development of a network of Centers for the Provision of Administrative Services (CPAS). Currently, most of the ATCs of Ivano-Frankivsk region carry out work on the establishment and modernization of the CPAS.

Kotenko \& Illiashenko [12] stresses the need for a reform of financial decentralization in Ukraine. In particular, it is very important for the longterm perspective to achieve political consensus on identifying the best strategies for reforming local self-governance, which will include creating conditions for entrepreneurship development, strengthening cooperation with the private sector and attracting foreign investment to local self-government bodies [28, p. 52].

\section{Conclusions}

Priority directions of activity of territorial communities of the region, as well as of the whole country, are in the first place:

- repair of highways;

- assistance in the preparation of city-planning documentation;

- development of alternative energy.

As the foreing experience of the past in overcoming the existing challenges to local self-government proved, it became possible under the conditions of transition from the traditional representative (where citizens, in order to protect their interests, elect their representatives to power) to a participatory democracy based on the principles of direct control of the state, society and separate territory by the community of free citizens. The main advantages of participatory democracy are: the opportunity for each individual to realize his or her public potential; overcoming absenteeism; changes in the attitude of authorities to citizens, recognition of the priority of their rights and freedoms, and, as a consequence, raising confidence to the authorities themselves; the rebirth of citizens' sense of social justice.

An analysis of foreign experience has allowed to highlight the most important measures to strengthen the interaction of local authorities and people in Ukraine: the publication of annual reports on its activities to ensure transparency of actions of local authorities; promoting the development of volunteer movements; moral and material encouragement of the citizens; development of cooperation between public organizations and organizations of local entrepreneurs; creation of voluntary alliances of activites in support of politics, conducted by local authorities; creation of specialized computer systems for communication with inhabitants of the territory; use of modern information technologies, in particular electronic governance.

It should be noted that the decentralization of management is not a panacea and a guarantee of rapid improvement of the quality of life of the population in the communities, however, it significantly expands the opportunities for better provision of various territorial communities with the necessary services and more qualitative use of local resources. Therefore, choosing the country's 
most appropriate peculiarities, the model of decentralization in the mediumterm perspective can be expected by qualitative positive results of investment activity.

\section{References:}

1. Akimova, L. M., Litvinova, I. F., Ilchenko, H. O., Pomaza-Ponomarenko, A. L. \& Yemets O. I. (2020). The Negative Impact of Corruption on the Economic Security of States. International Journal of Management, 11(5): 1058-1071. Retrieved from: http://www.iaeme.com/IJM/issues.asp?JType=IJM\&VType =11\&IType=5

2. Armey, L. E. \& McNab, R. M. (2018). Expenditure decentralization and natural resources. Quarterly Review of Economics and Finance. 70: 52-61.

3. Barro, R. (1991). Economic growth in a cross section of countries. Quarterly Journal of Economics. 106: 407-443.

4. Bezverkhniuk, T (2007). The Role of the Principles of «European Regionalism» in the Organization of the National System of Regional Management The electronic scientific professional edition of the Odessa Regional Institute of Public Administration of the NAPA under the President of Ukraine. April 20, 2019. Retrieved from: http://www.nbuv.gov.ua/e-journals/tppd/ index.html (in Ukrainian)

5. Bondaruk, T. G. \& Bondaruk, I. S. (2019). State regulation of financial support of municipal authority under decentralisation conditions. Scientific Bulletin of Polissia, 4: $16-21$.

6. Bykadorova, N. O. (2010). Financial decentralization of local self-government. Economic Newsletter Donbass. 2(20). Retrieved April 1, 2019. Retrieved from: http://dspace.nbuv.gov.ua (in Ukrainian)

7. Decentralization: Experiments and Reforms (2016). Edited by Tamas M. Horvath. Budapest: OSI/LGI, 424.

8. Decentralization results of the year in Ivano-Frankivsk region. (2019). February 15, 2019. Retrieved from: http://www.if.gov.ua/news/decentralizacijni-pidsumki-roku-naivano-frankivshini (in Ukrainian)

9. Diamond, L. (2014). «Why Decentralize Power in A Democracy?» Conference on Fiscal and Administrative Decentralization, Baghdad, Iraq, February 12, February 25, 2019. Retrieved from: https://web.stanford.edu/ ldiamond/iraq/Decentralize_Power 021204.htm

10. In Precarpathia, another 11 ATCs received the right to dispose of land outside settlements. (2019). March 15, 2019. Retrieved from: https://zik.ua/news/2018/09/27/ na_prykarpatti_shche_11_otg_otrymaly_pravo_rozporyadzhatysya_zemleyu_za_mezhamy_ 1415281 (in Ukrainian)

11. Financial decentralization and budget of the first 159 community objects - details (+ presentation). March 8, 2019. Retrieved from: https://decentralization.gov.ua/en/news/ 5244 (in Ukrainian)

12. Kotenko, N. V. \& Illyashenko, T. O. (2015). Fiscal decentralization and the challenges of public ecological services delivery. Marketing and management of innovations, 2: 267-278.

13. Kovalenko, H. V., \& Topolskova, D. S. (2017). Introduction of Public Power Decentralization based on the experience of European Countries. Scientific bulletin of Uzhgorod National University, 13(1): 120-123. (in Ukrainian)

14. Kozak, I., Balaniuk, I., Balaniuk, S., Szelenko, D., Kozak, H. (2019). Traditional village system - case study from the Krempna Commune (Poland). The Journal of Institute of Landscape Ecology of Slovak Academy of Sciences, 38(1): 87-100.

15. Levitas, A. (2018). Local government reform as state building: What the Polish case says about «decentralisation» Zarządzanie Publiczne Public Governance, No. 3(45): 5-25. 
16. Levitas, A. (1992). Rethinking reform: Lessons from Polish privatization. World Policy Journal, 9(4): 779-794.

17. Main Department of Statistics Ivano-Frankivsk region Website. Retrieved March 28, 2019, from: http://www.ifstat.gov.ua/

18. Ministry of Finance Website. Retrieved from: https://index.minfin.com.ua/economy/ gdp/2018 (in Ukrainian)

19. Pitt, M. M. \& Menon, N. (2019). Spatial Decentralization and Programme Evaluation: Theory and an Example. Oxford bulletin of economics and statistics, 81(3): 511-539.

20. Rondinelli, D. (2015). Decentralizing Urban Development Programs: A Framework for Analizing Policy. Washington D.C.: USAID, 124.

21. Shelenko, D. (2018). International transfer of technologies as a factor of technical upgrade and modernization of agricultural enterprises. Agrarian economy, 11(3-4): 41-47.

22. Shyam Sunder (2017). Financial Regulation for a Better Society. Account Econ Law; 7(2): 51-58.

23. Skrypniuk, O. (2014). Problems of ensuring state sovereignty of Ukraine at the present stage (constitutional-legal aspect). Bulletin of the National Academy of Legal Sciences of Ukraine. 2: 18-26. Retrieved March 15, 2019, from: http://nbuv.gov.ua/ UJRN/vapny_2014_2_4 (in Ukrainian)

24. Stavytskyi, A. V. (2014). The role of state expenditures in ensuring economic growth in Ukraine. Global and national problems of the economy. 2. Retrieved March 13, 2019, from: http://global-national.in.ua/vipusk-1-2014/319-stavitskij-a-v-rol-derzhavnikhvidatkiv-u-zabezpechenni-ekonomichnogo-zrostannya-v-ukrajini

25. Svitovyy bank Website. Retrieved February 15, 2019, from: http://www.worldbank.org (in Ukrainian)

26. Tkachuk, A. (2015). Scandinavian way. Experience the reform of administrative and territorial structure and local governments of Denmark and in Sweden. Kyiv: Logos, 124. (in Ukrainian)

27. Vasylchenko, S. M, \& Zavysliak, M. V. (2017). Management of local economic development in conditions of economic decentralization «Social and economic development of the region: current realities and prospects»: Monograph. Ivano-Frankivsk: Publisher of MPP «Tale». 7(1). (in Ukrainian)

28. Vesna, M., Milica, G. \& Dusan M. (2015). Current issues of local self-government financing in the republic of Serbia in the process of decentralization. 5th Eastern European Economic and Social Development Conference on Social Responsibility (ESD). Varazdin Dev \& Entrepreneurship Agcy, Belgrade, Serbia: 50-59.

29. Yakubiv, V. M., Shelenko, D. I., Sas, L. S. (2015). Fixed assets accounting: National and international aspects. Actual Problems of Economics, 11 [173]: 375-379. (in Ukrainian)

30. Yemets, O. I. \& Korzhyk, O. M. (2017). Local social and development in a global economy. Materials of the All-Ukrainian Scientific and Practical Internet Conference «Science of the 3rd Millennium: Searches, Problems, Prospects of Development» Berdyansk: BDPU, 1: 45-47. (in Ukrainian) 